University for Business and Technology in Kosovo

UBT Knowledge Center

UBT International Conference

2017 UBT International Conference

Oct 28th, 11:00 AM - 12:30 PM

\title{
Differential Diagnosis between the Variety of Vasculitis Forms
}

Joana Hankollari

Albanian University, joanahankollari@gmail.com

Marsida Duli

Universiteti Europian i Tiranes

Qamil Dika

Universiteti Ismail Qemali, qamil_dika@yahoo.com

Xhenila Duli

Mjeke e Pergjithshme

Indrit Bimi

Alexander Moisiu University of Durrës

See next page for additional authors

Follow this and additional works at: https://knowledgecenter.ubt-uni.net/conference

Part of the Medicine and Health Sciences Commons

\section{Recommended Citation}

Hankollari, Joana; Duli, Marsida; Dika, Qamil; Duli, Xhenila; Bimi, Indrit; and Dervishi, Daniela, "Differential Diagnosis between the Variety of Vasculitis Forms" (2017). UBT International Conference. 288.

https://knowledgecenter.ubt-uni.net/conference/2017/all-events/288

This Event is brought to you for free and open access by the Publication and Journals at UBT Knowledge Center. It has been accepted for inclusion in UBT International Conference by an authorized administrator of UBT Knowledge Center. For more information, please contact knowledge.center@ubt-uni.net. 


\section{Presenter Information}

Joana Hankollari, Marsida Duli, Qamil Dika, Xhenila Duli, Indrit Bimi, and Daniela Dervishi 


\title{
Differential Diagnosis between the Varieties of Vasculitis Forms
}

\author{
Joana Hankollari ${ }^{1}$, Marsida Duli ${ }^{2}$, Qamil Dika ${ }^{3}$, Xhenila Duli ${ }^{4}$, Indrit Bimi ${ }^{5}$, Daniela \\ Dervishi $^{5}$ \\ ${ }^{1}$ Fakulteti i Shkencave Mjekësore, Albanian University, Tiranë \\ ${ }^{2}$ Universiteti Europian i Tiranes \\ ${ }^{3}$ Universiteti Ismail Qemali \\ ${ }^{4}$ Mjeke e Pergjithshme \\ ${ }^{5}$ Alexander Moisiu University of Durrës \\ joanahankollari@gmail.com
}

\begin{abstract}
Vasculitis is an inflammation of the blood vessels. It can affect any blood vessel in the body by manifesting a variety of systemic, non-specific symptoms that make difficult the diagnosis of this pathology and especially its specific form. In front of any patient suspected of being affected by vasculitis, some questions are asked: Is the vasculitis or other pathology that camouflages, whether it is primary or secondary vasculitis, in which vessels this pathology extends, how can the diagnosis be confirmed and how can it be determined the type of vasculitis? The purpose of this study is to inform about the protocols to be followed to perform differential diagnosis of vasculitis types. This study is a review based on the research of world studies and literature regarding the recommendations for performing differential diagnosis among the variety of vasculitis forms. Primary patient assessment involves taking the history of the medications it uses, risk factors for infectious pathology, history of cardiac valve pathologies, and autoimmune pathologies. Then laboratory and imaging studies are carried out, aiming at setting the diagnosis, determining the affected organ and the degree of disease activity. And recently we refer to algorithms to make differential diagnosis between the varieties of vasculitis forms. Despite the diagnostic difficulties of vasculitis, the variety of its forms, the separation of responsibilities among many specialities, there are protocols that need to be followed rigorously to arrive at a safe diagnosis as well as auxiliary algorithms to distinguish the type of vasculitis.
\end{abstract}

Keywords: vasculitis, differential diagnosis, protocols.

\section{Introduction}

Vasculitis is an inflammation of the blood vessels, which may affect vessels of different caliber and in any part of the body. Vascular patients may exhibit cutaneous lesions, which are typical of vasculitis in small blood vessels, or in the field of another autoimmune connective tissue disease. In some cases predominate symptoms and signs such as temperature, anorexia, weight loss, bodily weakness that may be in the context of a neoplasia or an infectious disease. In order to make a rapid diagnosis of vasculitis and its specific form, a generalized objective examination of the patient is required in clinical practice, starting with skin examination, musculoskeletal examination, neurological examination, and other vital organs. We should also look for signs of local ischemia.

Vascular inflammation can cause destruction of the blood vessel wall or stenosis of their lumen. Destruction of the blood vessel wall can result in an anerurism or rupture of the vessel. The 
stenosis of lumen can cause ischemia, necrosis of the region that the vessel vascularises. Vasculitis can be primary or secondary, so it can not be evidenced a specific cause of it and remain idiopathic or it can be a consequence of another pathology. Not always the basic pathology is known and this fact makes the diagnosis of vasculitis even more complicated. Diagnosis is provided by our clinics, laboratory and imaging examinations such as: skin biopsy, angio CT or angio MRI, ANCA etc.

In performing differential diagnosis, an important role plays the classification of vasculitis, which has been updated several times over the years and still does not have a definitive form that can guarantee a safe diagnosis. There are many factors influencing, for example: false negativity or false positivity of ANCAs, non-specific distribution of inflammation, overlap of some forms, existence of primary and secondary forms. Of clinical significance is the evaluation of the activity of this pathology, its complications and prognosis, and the treatment strategies.

\section{Various forms of vasculitis}

\section{Classification of different forms of vasculitis}

Based on the 2012 Chapel Hill Consensus Conference nomenclature, we classify the vasculitis according to vessels size they affect and their number: vasculitis of large vessels, medium vessel vasculitis, small vessel vasculitis, vasculitis of small and medium vessels that is associated with the presence of ANCA antibody, the variable vessel vasculitis, single organ vasculitis. Each of these forms may be a primary idiopathic or secondary vasculitis as a result of another pathology. The following table presents in detail this classification.

Large caliber vessels that affect the vasculitis include the aorta and its branches such as the subclavian, axillary, carotid, and cerebrovascular arteries. Medium caliber vessels include the main visceral arteries such as renal, mesenteric etc. Small caliber vessels include arterioles, capillaries and venules. 
Table 1. Classification of different forms of vasculitis ${ }^{1}$

\begin{tabular}{|c|c|c|}
\hline Dominant vessel & Primary disorders & Secondary disorders \\
\hline Large arteries & $\begin{array}{l}\text { Takayasu's arteritis } \\
\text { Giant cell arteritis }\end{array}$ & $\begin{array}{l}\text { Infection: bacterial, fungal, } \\
\text { mycobacterial, spirochaetal } \\
\text { Rheumatoid arthritis } \\
\text { Seronegative } \\
\text { spondylarthropathy } \\
\text { Systemic } \\
\text { erythematosus } \\
\text { Sarcoidosis } \\
\text { Relapsing polychondritis } \\
\text { Juvenile chronic arthritis }\end{array}$ \\
\hline Medium arteries & $\begin{array}{l}\text { Poliarteritis nodosa } \\
\text { Kawasaki disease }\end{array}$ & $\begin{array}{l}\text { Infection, e.g. hepatitis B. } \\
\text { Hairy cell leukaemia }\end{array}$ \\
\hline Small/medium vessels & $\begin{array}{l}\text { Granulomatosis with } \\
\text { polyangiitis } \\
\text { Eosinophilic granulomatosis } \\
\text { with polyangiitis } \\
\text { Microscopic poliangiitis }\end{array}$ & $\begin{array}{l}\text { Vasculitis secondary to } \\
\text { autoimmune disease. } \\
\text { Malignancy. Drugs. } \\
\text { Infection, e.g. HIV }\end{array}$ \\
\hline Small vessels & $\begin{array}{l}\text { Henoch-Schönlein purpura } \\
\text { Essential mixed } \\
\text { cryoglobulinaemia. }\end{array}$ & $\begin{array}{l}\text { Drugs. Malignancy. } \\
\text { Infection, e.g. hepatitis B/C }\end{array}$ \\
\hline Variable vessels & $\begin{array}{l}\text { Behçet's disease } \\
\text { Cogan syndrome }\end{array}$ & \\
\hline Single organ vasculitis & $\begin{array}{l}\text { Primary CNS vasculitis, } \\
\text { cutaneous angiitis }\end{array}$ & \\
\hline
\end{tabular}

\section{Clinic of primary forms of vasculitis}

To determine the secondary forms, the doctor should be a good internist or general practitioner to clinically suspect and then laboratory or imaging way certify the patient's basic pathology. While primary forms have well-defined diagnostic criteria from the American College of Rheumatology and the recommendations of the European League Against Rheumatism. Without going into detailed protocols that are most accessible to everyone, I present some of the predominant clinical manifestations for each primary form.

${ }^{1}$ Oxford American Handbook of Rheumatology, second edition, page 420, 421. 
Table 2. The most common vasculitic syndromes: age group, sex and main clinical manifestations. ${ }^{2}$

\begin{tabular}{|l|l|l|l|}
\hline Primary form & $\begin{array}{l}\text { Age } \\
\text { group }\end{array}$ & $\begin{array}{l}\text { Sex } \\
\text { (M-F) }\end{array}$ & Predominant clinical manifestation \\
\hline Polyarteritis Nodosa & $40-60$ & $2: 1$ & $\begin{array}{l}\text { Fever, weight loss, livedo reticularis, } \\
\text { mono- or polyneuropathy, } \\
\text { arterial hypertension. }\end{array}$ \\
\hline $\begin{array}{l}\text { Granulomatosis with } \\
\text { poliangiitis }\end{array}$ & $30-50$ & $1: 1$ & $\begin{array}{l}\text { Sinusitis, mouth ulcers, otitis, hemoptysis, } \\
\text { pulmonary nodules, } \\
\text { nephritis }\end{array}$ \\
\hline $\begin{array}{l}\text { Eosinophilic } \\
\text { granulomatosis with } \\
\text { poliangiitis }\end{array}$ & $40-60$ & $2: 1$ & $\begin{array}{l}\text { Severe asthma, atopic eczema, mono- or } \\
\text { polyneuropathy, } \\
\text { pulmonary infiltration, eosinophilia.. }\end{array}$ \\
\hline $\begin{array}{l}\text { Leukocytoclastic } \\
\text { Vasculitis }\end{array}$ & $30-50$ & $1: 1$ & $\begin{array}{l}\text { Often associated with other CTDs and } \\
\text { drugs, palpable } \\
\text { purpura, maculopapular erythema, skin } \\
\text { ulceration }\end{array}$ \\
\hline $\begin{array}{l}\text { Henoch-Schônlein } \\
\text { purpura }\end{array}$ & $5-20$ & $1: 1$ & $\begin{array}{l}\text { Palpable purpura, maculopapular } \\
\text { erythema, skin ulceration } \\
\text { (usually in lower limbs and buttocks), } \\
\text { abdominal pain, bloody } \\
\text { diarrhea, nephritis with deposition of IgA. }\end{array}$ \\
\hline Giant cell vasculitis & $60-75$ & $1: 3$ & $\begin{array}{l}\text { Temporal pain, masticatory claudication, } \\
\text { stiffness } \\
\text { of the scapular and pelvic girdles, double } \\
\text { vision, sudden } \\
\text { sight loss. }\end{array}$ \\
\hline Urticarial vasculitits & $20-35$ & $1: 1$ & $\begin{array}{l}\text { Mouth and genital ulcers, pseudo- } \\
\text { folliculitis of the skin, thrombophlebitis, } \\
\text { uveitis (sight loss), throm } \\
\text { arthritis. }\end{array}$ \\
\hline $\begin{array}{l}\text { Palpable purpura, urticarial lesions with } \\
\text { residual scarring, } \\
\text { skin nodules and ulcers. }\end{array}$ \\
\hline
\end{tabular}

If we cannot suspect that vasculitis is of secondary origin and this fact is excluded with examinations, the above table orientes us towards the differentiation of primary forms. In this table because of the variety of primary forms, not all forms are presented.

\section{Suspicion of secondary forms}

Secondary forms of vasculitis can be caused by:

1. Autoimmune diseases such as systemic erythematosus lupus, sarcoidosis, rheumatoid arthritis, rheumatoid juvenile arthritis, Crohn morbus, ulcerous colitis, and so on.

2. Infectious viral diseases such as hepatitis B, C, HIV, Cytomegalovirus etc; bacterial infectious diseases such as spiroketate, mycobacteria, streptococci etc; parasitic diseases; or mycotic ones such as aspergillus.

2 J.A.P. Da Silva, A.D. Woolf, Rheumatology in Practice, Page 25.31 
3. Neoplasms such as: Hodgkin's lymphoma, myeloproliferative diseases, solid tumors, atrial muscles, and so on.

4. Drug Injuries

5. Use of certain medications such as hydralazine, propylthiouracil, metimazole, carbamizole, azithromycin, penicillamine, leukotriene receptor antagonists.

Patients with secondary forms of vasculitis in most cases exhibit a baseline pathology clinic especially in the case of autoimmune, intoxication or bacterial, mycotoxic, parasitic diseases. For viral infections there is a protocol of examinations that reveal the presence of the virus or not. In the patient's history we should be careful about the medications he uses, the duration of treatment, other risk factors of the patient. The most difficult part of the diagnosis are undiagnosed neoplasms which have not yet appeared in a specific clinic. In this case, we help the patient's condition, such as bodily weakness, immediate weight loss, changes in laboratory or basic imaging, family history, neoplasia etc.

\title{
Diagnosis of vasculitis
}

To establish the diagnosis of vasculitis, consider these steps to avoid direct invasive procedures:

1. Obtaining anamnesis and conducting an objective examination.

- exposure to medication

- risk factors for hepatitis B / C / HIV

- History of cardiac valve diseases

-Questions about autoimmune diseases

- Objective examination by identifying symptoms and general signs such as temperature, weight loss, bodily weakness etc.

-Confirmation of objective examination in systems where vasculitis is directed to symptoms such as: purpura, ulceration, skin infarction; sinusitis, epistaxis; cough, hemoptysis, dyspnoea, chest pain, diarrhea, abdominal pain, oral ulcers, neurological touches of motors and sensors, etc.

2. Carry out laboratory analyzes

- Laboratory analyzes aimed at evidencing the presence of inflammation, such as complete blood and erythrocyte, reactive $\mathrm{C}$ protein; heparin evidence; nitrogen, creatinine, complete urine. - Biopsy of cutaneous lesions

- Immunological tests such as ANCA, rheumatoid factor, ANA, anti ds DNA, anticardiolipin, complement, cryoglobulin etc.

-Microbiological tests such as: isolation of microbial cultures.

\author{
3. Perform imaging examinations \\ -abdominal ultrasound \\ - pulmonary radiographs \\ -electrocardiogram, cardiac ultrasound \\ -angiography etc
}

\section{Differential diagnosis between the variety of vasculitis forms.}

Differential diagnosis of vasculitis is very important because there are relatively benign forms that may be regressive and self-exerted, as there are aggressive forms of vasculitis that require high doses of immunosuppressive agents as they carry high mortality risk. To achieve differential diagnosis among different types of vasculitis it is necessary to go through these stages: 
1. Are we dealing with vasculitis or a pathology that camouflages it?

2. Are we facing a secondary form as a result of another existing pathology?

3. What is the spread of vasculitis?

4. How to confirm the diagnosis of vasculitis?

5 . How to determine its specific form?

Pathologies that mimic vasculitis include: infectious endocarditis, atrial muscle, cholesterol embolism, antiphospholipid syndrome, vasoconstrictive medications. Exempting the camouflage pathologies help us laboratory and imaging examinations. These examinations help us to differentiate primary forms from secondary ones. If in the complete blood test we have leukocytosis, we may have a primary form or an infection. If we have leucopenia, it can be a vasculitis of an autoimmune connective tissue pathology. Eosinophils grow in vasculitis from medications but also in eosinophilic polylenic granulomas. Liver tests are not very specific but in case of high values, viral hepatitis should be considered. In urine analysis, hematuria, primary proteinuria and leukocyte presence appear in secondary forms. Also renowned renal function, creatinine, creatinine clearance, and often renal biopsies make differential diagnosis with primary forms. Tumor markers and imaging examinations help us detect various tumors. Termination of the drug or its replacement with another associated with regression of the symptoms orientates us to the secondary form of medicament vasculitis. The positiveness of immune tests leads us to autoimmune connective tissue diseases or the presence of infections depending on the test. After we have excluded secondary forms we concentrate on the extent of vasculitis based on the clinic and performing according to the protocol complete urinary analysis, renal ultrasound, pulmonary radiography, CK measurement, and performing ENG, EMG. Once we get their response and then we confirm the diagnosis with invasive methods that without a database we could not do. Here we mention the vascular biopsy and angiography. After confirming the inflammation of the vessels, we evaluate ANCA, cryoglobulin, complement, IgE level and number of eosinophils, specific findings in the biopsy such as IgA deposits etc. For the most detailed differential diagnosis protocol, it can be consulted on the ARUP consult algorithms, Vasculitis in Adults Testing Algorithm. The following table shows the path to be followed to carry out differential diagnosis of different forms of vasculitis.

Table 3. Tests for differential diagnosis of different forms of vasculitis ${ }^{3}$

Exclusion of similar vasculititis pathologies and its secondary forms.

Blood cultures

Electrocardiogram

Hepatitis B / C Tests

HIV test

Antiphospholipid antibodies

Antinuclear antibodies

Antibodies to the Glomerular Basal Membrane

Determining the extent of vasculitis

Complete urine

Pulmonary radiography

ENG, EMG, CK

Confirmation of vasculitis diagnosis

Biopsy and angiogram

3 Postgrad Med J 2006;82:483-488. doi: 10.1136/pgmj.2005.042648 
Identification of the specific form of vasculitis

\section{ANCA}

Complement level

Cryoglobulins

Number of eosinophils, IgE level

Specific findings in the biopsy such as IgA deposition and so on

In addition to differential diagnosis, treatment of vasculitis is important and determines disease activity, disease damage, and prognosis. All three of these elements are achieved through the Birmingham Vasculitis Activity Score (BVAS), the Vasculitis Damage Index (VDI), the Five Factor Score (FFS).

\section{Conclusions}

Despite the diagnostic difficulties of vasculitis, the variety of its forms, the separation of responsibilities between many specialties, there are protocols that need to be followed rigorously to arrive at a safe diagnosis as well as auxiliary algorithms to distinguish the type of vasculitis. Firstly, vasculitis as a diagnosis must be suspected in all cases when the symptoms and signs of the patient are multisistemic, the pathology that mimics it and the secondary forms must be excluded, then the diagnosis must be confirmed. Once diagnosis has been made, differentiation between primary forms that have different prognoses should be made. This is the key to better treat vasculitis. It should not be forgotten either the evaluation of its activity, the damage it has caused.

\section{References}

1. E. Suresh, Diagnostic approach to patients with suspected vasculitits, Postgrad Med J 2006;82:483-488. doi: 10.1136/pgmj.2005.042648.

2. W. L. Gross, A. Trabandt and E. Reinhold-Keller, Diagnosis and evaluation of vasculitis, Rheumatology 2000;39:245-252.

3. Teng GG, Chatham WW, Vasculitis related to viral and other microbial agents, Best Pract Res Clin Rheumatol. 2015 Apr;29(2):226-43. doi: 10.1016/j.berh.2015.05.007. Epub 2015 Jun 11.

4. Pulido-Pérez A, Avilés-Izquierdo JA, Suárez-Fernández R, Cutaneous vasculitis, Actas Dermosifiliogr. 2012 Apr;103(3):179-91. doi: 10.1016/j.ad.2011.06.001. Epub 2011 Aug 12.

5. Holl-Ulrich K, Vasculitis: New nomenclature of the Chapel Hill consensus conference 2012, Z Rheumatol. 2014 Nov;73(9):823-33; quiz 834-5. doi: 10.1007/s00393-014-1477-x

6. Sunderkötter C. [Skin manifestations of different forms of vasculitis]. Z Rheumatol. 2013 Jun;72(5):436-44. doi: 10.1007/s00393-013-1136-7. Review. German. PubMed PMID: 23743986.

7. Loricera J, Blanco R, Hernández JL, Martínez-Rodríguez I, Carril JM, Lavado C, Jiménez M, González-Vela C, González-Gay MÁ. Use of positron emission tomography (PET) for the diagnosis of large-vessel vasculitis. Rev Esp Med Nucl Imagen Mol. 2015 Nov- 
Dec;34(6):372-7. doi: 10.1016/j.remn.2015.07.002. Epub 2015 Aug 10. Review. English, Spanish. PubMed PMID: 26272121.

8. Grayson PC, Amudala NA, McAlear CA, Leduc RL, Shereff D, Richesson R, Fraenkel L, Merkel PA. Causal attributions about disease onset and relapse in patients with systemic vasculitis. J Rheumatol. 2014 May;41(5):923-30. doi: 10.3899/jrheum.131096. Epub 2014 Mar 15. PubMed PMID: 24634202; PubMed Central PMCID: PMC4008683.

9. Sharma A, Dhooria A, Aggarwal A, Rathi M, Chandran V. Connective Tissue DisorderAssociated Vasculitis. Curr Rheumatol Rep. 2016 Jun;18(6):31. doi: 10.1007/s11926-0160584-x. Review. PubMed PMID: 27097818. 